\title{
Reconnaissance work in the Triassic of the Wandel Sea Basin, Peary Land, eastern North Greenland
}

\section{Eckart Håkansson and Claus Heinberg}

The North-eastern part is one of the geologically least known areas in Greenland and although late Palaeozoic, Mesozoic and Tertiary strata are known to comprise the Wandel Sea basin, little stratigraphical and structural detail is available (for summaries see Peel et al., 1974; Dawes, 1976). As a forerunner to GGU's forthcoming regional mapping project in northern Greenland, a reconnaissance tour to the Wandel Sea basin was attempted through the courtesy of the Royal Danish Air Force. However, due to partial failure in logistic support the field work was severely restricted and only part of the eastern Peary Land sequence was visited. Here only a single section was measured.

\section{Location of the section}

The present profile is situated approximately $20 \mathrm{~km}$ WNW of Kap Eiler Rasmussen, on the eastern side of Kim Fjelde (fig. 4), on the flank of an elongate, flat-topped mountain which rises to approximately $625-650 \mathrm{~m}$ above the broad, low Herlufsholm Strand.

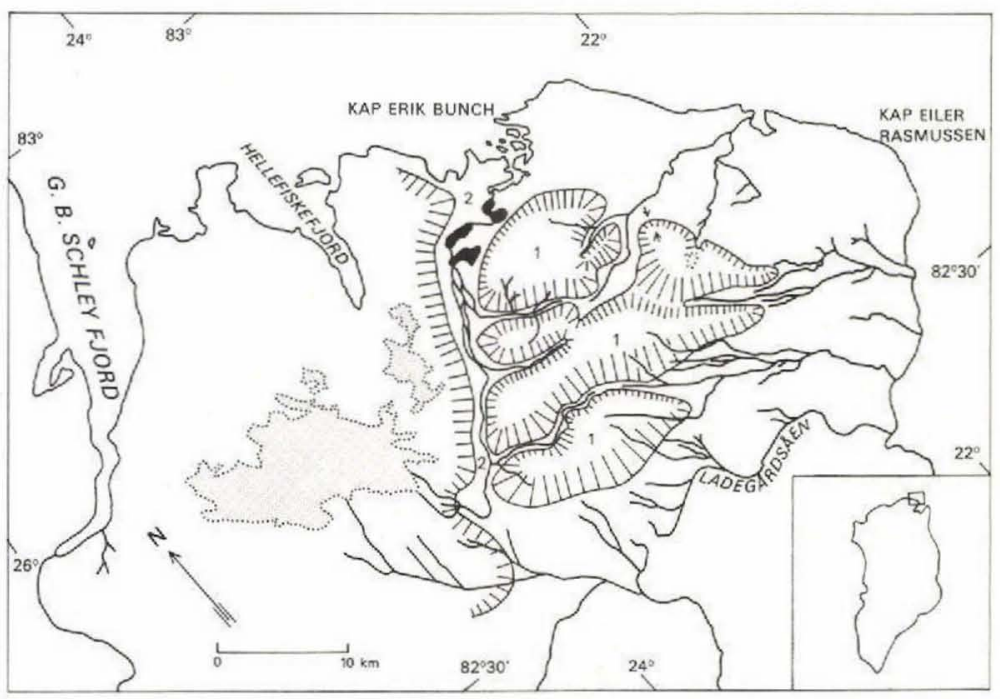

Fig. 4. Topographic sketch map of the Kim Fjelde area, eastern Peary Land based on Geodetic Institute aerial photograph uncontrolled mosaics, 1:100 000. 1: Kim Fjelde; 2: Foldedal. Black: lake; stippled: ice; barred lines: slope, with closer spacing of bars representing severity of slope; arrows: position of measured profile illustrated in fig. 5 . 
Unfortunately, topographic coverage of the area is of poor quality and appreciable problems occurred trying to locate earlier collecting sites. This is particularly true for the Triassic locality "Store Kløft" worked by J. C. Troelsen (in Kummel, 1953), and indicated schematically on a small-scale geological map (Troelsen, 1956, fig. 2). Laursen (1972) followed by Peel et al. (1974), misplace this locality towards the eastern corner of Peary Land (Kap Eiler Rasmussen). However, it is likely that the section measured by Troelsen is situated close to our profile (fig. 6).

Furthermore, it transpires that our locality is included in the region described by Koch (1929a, b and references therein) as composed of Carboniferous strata. Although rather vague, Koch's description of rocks and topography fits the siutation at Kim Fjelde, and a photograph (Koch 1929a, p. 93) confirms this. This photograph shows part of the northernfacing slope of Kim Fjelde, in which, despite the snow cover, the section visited by us can be located (fig. 5). However, as discussed below, the entire sequence encountered in this section is Triassic, so the late Palaeozoic fauna mentioned by Koch (1929a, p. 94) must have originated from elsewhere in the area. For example, Permo-Carboniferous deposits have been reported by Troelsen (1950, 1956, fig. 2) somewhat to the north-west (see Petryk, this report). Regrettably, Troelsen did not publish a full account of his field work in eastern Peary Land (Peel et al., 1974) and so never had occasion to compare the location of his Triassic section (in Kummel, 1953) with the earlier observations of Lauge Koch.

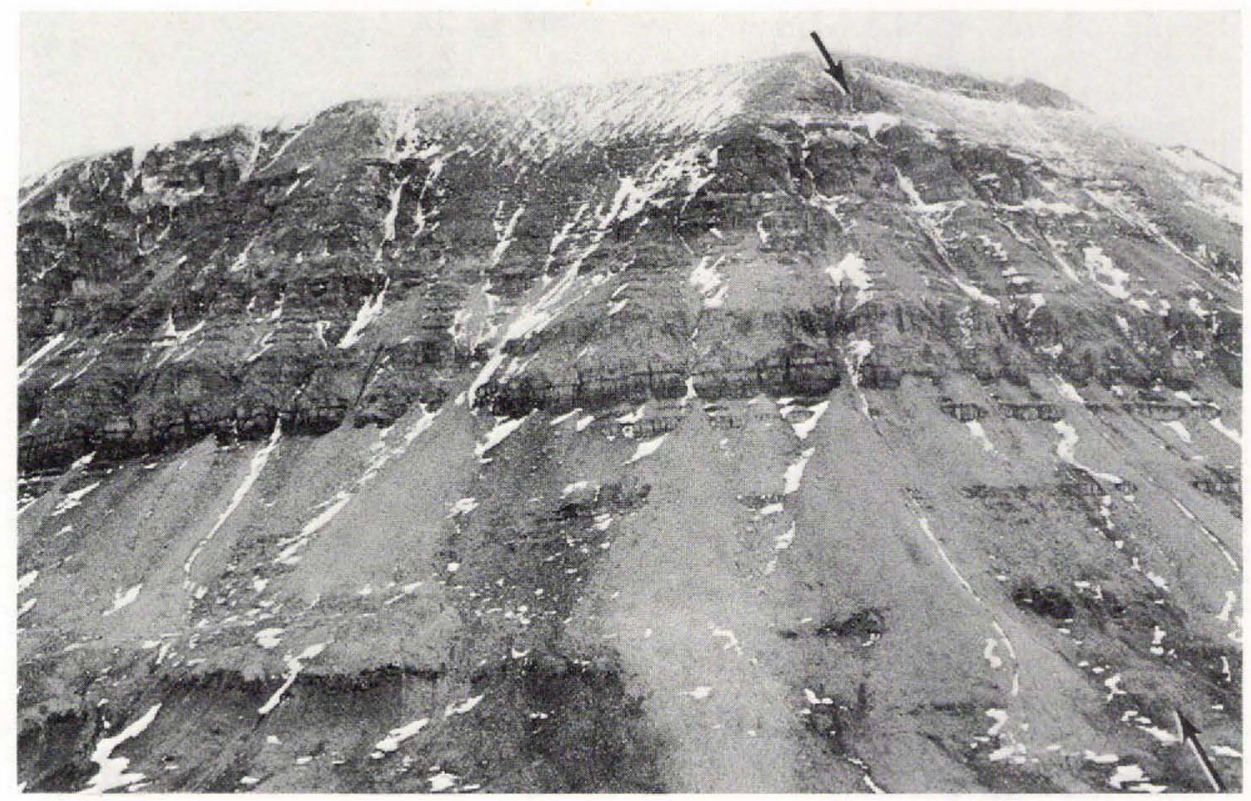

Fig. 5. Helicopter view of the measured profile (indicated by arrow) eastern Kim Fjelde, Peary Land. 


\section{General geology}

Herlufsholm Strand has an extensive cover of marine Quaternary deposits (Troelsen, 1952) but the overall topography of the platform undoubtedly reflects the eroded surface of the North Greenland fold belt on which the sediments of the Wandel Sea basin accumulated (Dawes \& Soper, 1973). However, since the lower slopes of the investigated part of Kim Fjelde are everywhere covered with scree, nothing can be inferred about the relationship between the two rock suites. In places isolated shale sequences are found almost down to the platform but they appear to have been displaced by landslides; the lowest reliable outcrops have been found at an altitude of $225 \mathrm{~m}$.

Structurally the part of the Wandel Sea basin preserved in eastern Peary Land appears to be dominated by a number of small blocks controlled by high-angle faults. A regional trend from NW to SE is apparent in the general topography, but monor(?) faults with diverging directions are abundant.

\section{The measured section}

In general terms the measured section (fig. 6) comprises a lower mainly shaly unit with a somewhat varied lithology, and an upper more monotonous unit dominated by fine-grained, generally well sorted quartz sandstones. Shaly intervals are typically dark, in part due to very fine carbonaceous debris. Similarly, dispersed carbonaceous material gives the sandstones between 373 and $510 \mathrm{~m}$ a dark greyish to brownish colour when fresh. The carbonaceous material in these sandstones is sometimes evenly dispersed but may also be concentrated as drapings or partings. Very poor plant remains occasionally occur. However, irrespective of the presence of such organic matter, most sandstones weather to a common yellowish colour.

At present no formal lithological division is proposed, but a number of features can be mentioned which eventually may prove useful for correlation. Most prominent in this respect is the apparent restriction of phosphatic nodules to an interval from 452 to $488 \mathrm{~m}$ (see also Troelsen in Kummel, 1953), and the presence of $30 \mathrm{~m}$ of very dark shale somewhat higher in the section. Also, 'columnar' jointing in the massive sandstone between 375 and $380 \mathrm{~m}$ is characteristic (fig. 7) as is the topographic influence of the prominent sandstone units which forms shoulders at 310 and $360 \mathrm{~m}$ (fig. 6).

Between 275 and $287 \mathrm{~m}$ calcareous sandstone beds contain a fairly diverse but as yet undetermined fauna comprising disarticulated crinoids, brachiopods (terebratulids, rhynchonellids and orbiculoids), and lamellibranchs (various posidoniids, Hornesia sp., etc.) indicating a Triassic age. Around $\mathbf{4 2 5} \mathrm{m}$ poorly preserved ammonites were found in situ. They resemble Groenlandites nielseni Kummel and similarly indicate a Triassic age, most probably Middle Triassic (Anisian).

These ages agree with those proposed by Kummel (1953), and it is noteworthy that the genera Groenlandites and Pearylandites, formerly restricted to Peary Land, have now been found in both the Sverdrup basin and in British Columbia (Tozer, 1967). In the latter area they are contained in the fauna collected from the type section of the Caurus Zone, i.e. the lowest zone of the Anisian (Silberling \& Tozer, 1968).

Many intervals are moderately to strongly bioturbated obscuring primary sedimentary 

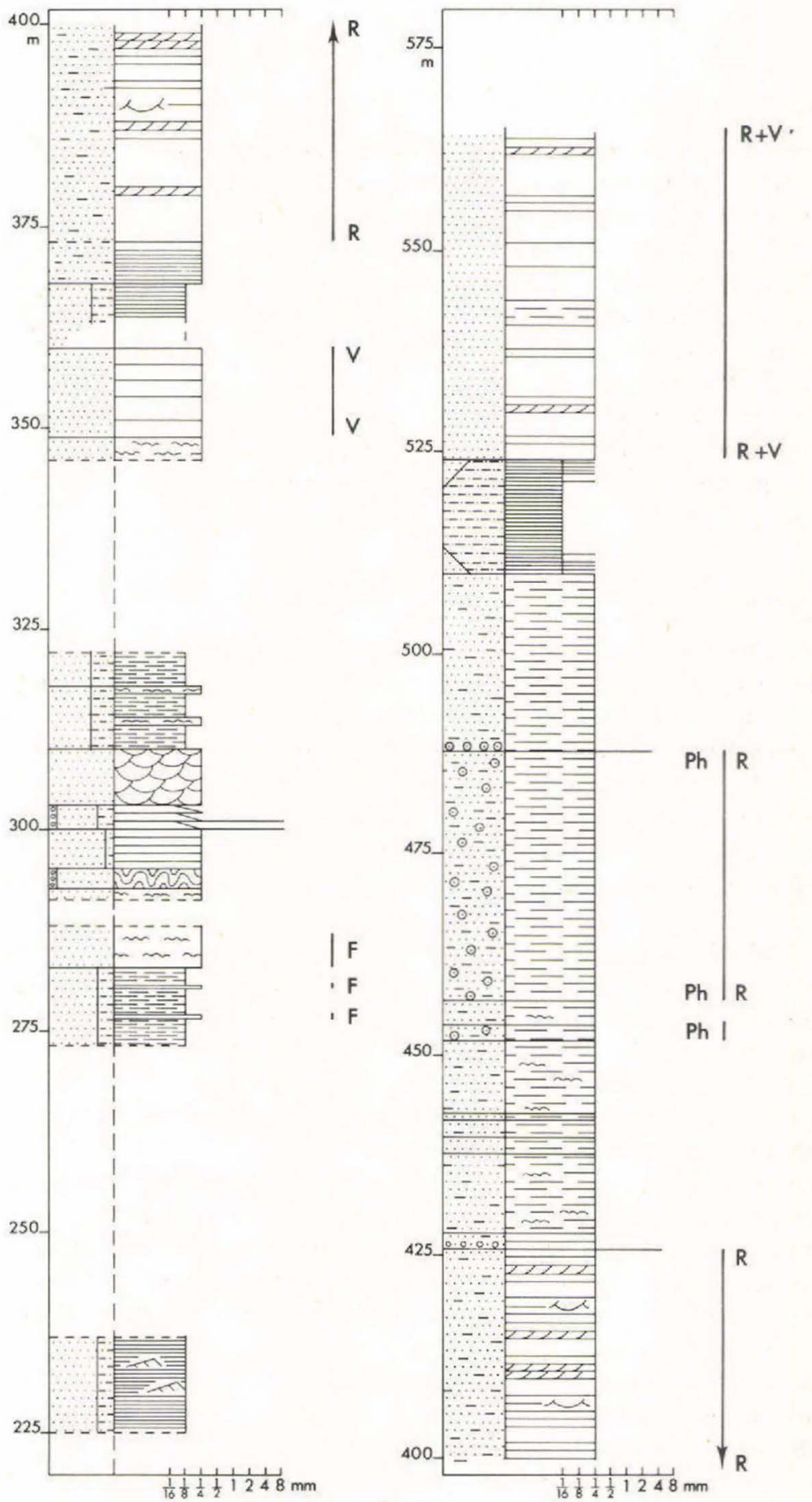

Fig. 6. Lithological profile in the Triassic sequence, eastern Kim Fjelde, Peary Land. 1: Siltstone; 2: Sandstone; 3: Conglomerate; 4: Concretions; 5: Laminated shale; 6: Irregularly bedded shale; 7: Flat-bedded sandstone; 8 : Irregularly bedded sandstone; 9 : Homogeneous sandstone; 10: Ripple marks; 11: Cross-bedding; 12: Trough cross-bedding; 13: Rubbly sandstone; 14: Ball and pillow structure. F: Body fossils; R: Rhizocorallium; V: Vertical tubes; Ph: Phosphatic nodules. 
Fig. 7. Characteristic 'columnar' jointing in the sandstone unit at $375-380 \mathrm{~m}$. Eastern Kim Fjelde, Peary Land.

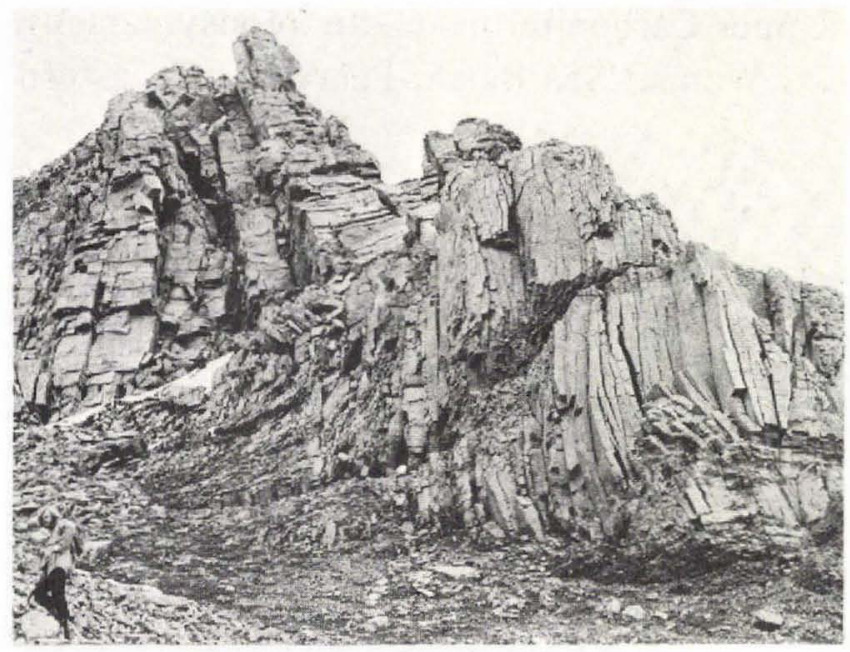

structures, but only Rhizocorallium and vertical tubes have been recorded undestroyed. In combination with the previously mentioned body fossils, however, these trace fossils undoubtedly indicate that the measured section represents a fully marine development in spite of the widespread comminuted carbonaceous debris.

\section{References}

Dawes, P. R. 1976: Precambrian to Tertiary of northern Greenland. In Escher, A. \& Watt, W. S. (edit.) Geology of Greenland 249-303. Copenhagen: Geol. Surv. Greenland.

Dawes, P. R. \& Soper, J. 1973: Pre-Quaternary history of North Greenland. Mem. Am. Ass. Petrol. Geol. 19, 117-134.

Koch, L. 1929a: The geology of East Greenland. Meddr Gronland 73 (2), 1, 204 pp.

Koch, L. 1929b: Stratigraphy of Greenland. Meddr Gronland 73 (2), 2, 205-320.

Kummel, B. 1953: Middle Triassic ammonites from Peary Land. Meddr Grønland 127, 1, 21 pp.

Laursen, D. 1972: The place names of North Greenland, Meddr Gronland 180, 2, $443 \mathrm{pp}$.

Peel, J. S., Dawes, P. R. \& Troelsen, J. C. 1974: Notes on some Lower Palaeozoic to Tertiary faunas from eastern North Greenland. Rapp. Gronlands geol. Unders. 65, 18-23.

Silberling, N. J. \& Tozer, E. T. 1968: Biostratigraphic classification of the marine Triassic in North America. Spec. Pap. geol. Soc. Am. 110. 63 pp.

Tozer, E. T. 1967: A standard for Triassic time. Bull. geol. Surv. Can. 156, 103 pp.

Troelsen, J. [C.] 1950: Geology. In Winther, P. C. et al. A preliminary account of the Danish Pearyland Expedition, 1948-9. Arctic 3, 6-8.

Troelsen, J. C. 1952: Notes on the Pleistocene geology of Peary Land, North Greenland. Meddr dansk geol. Foren. 12, 211-220.

Troelsen, J. C. 1956: The Cambrian of North Greenland and Ellesmere Island. In El sistema Cámbrico, su paleogeografia y el problema de su base. 20 Congr. geol. int. Mexico, Symp. 3, 1, 71-90.

Institut for historisk geologi og palaontologi, $\emptyset$ ster Voldgade 10, 1350 Copenhagen $K$. 